\title{
Understanding the Past to Envision a Sustainable Future: A Social-Ecological History of the Barranquilla Metropolitan Area (Colombia)
}

\author{
Juanita Aldana-Domínguez ${ }^{1,2, * \mathbb{B}}$, Carlos Montes ${ }^{1}$ and José A. González ${ }^{1}$ \\ 1 Social-Ecological Systems Laboratory, Department of Ecology, Universidad Autónoma de Madrid, \\ C/Darwin 2, 28049 Madrid, Spain; carlos.montes@uam.es (C.M.); jose.gonzalez@uam.es (J.A.G.) \\ 2 Caribbean Biodiversity Center, Departamento de Química y Biología, Universidad del Norte, \\ Km. 5 vía Puerto Colombia, Atlántico, Colombia \\ * Correspondence: juanitaldana@gmail.com or ajuanita@uninorte.edu.co; Tel.: +34-91-497-6778; \\ Fax: +34-91-497-8001
}

Received: 19 May 2018; Accepted: 27 June 2018; Published: 29 June 2018

\begin{abstract}
Urban growth is one of the major sustainability challenges due to its regional and planetary impacts. In the Colombian Caribbean, one of the most biodiverse places in the world, the Barranquilla Metropolitan Area (BMA) is the main urban agglomeration that has driven landscape transformation. We performed a historical analysis of human-nature relationships in the BMA using a social-ecological approach and the adaptive cycle metaphor to identify the main drivers of change and to point out emergent lessons for sustainability transition. Based on the analysis of existing literature, time series data and ecosystem distribution changes through time, we found that the natural capital has been degraded, human-social capital has had periods of crisis and recovery, while physical-financial capital has increased. The BMA is currently in a highly vulnerable situation and faces great challenges to be sustainable. We discuss the system's possible future paths: a new collapse due to natural capital depletion, stagnation in a very vulnerable state, or a reorganization. We argue that viewing and managing the BMA as a social-ecological system would contribute to move forward in a sustainable direction.
\end{abstract}

Keywords: social-ecological history; Colombia; adaptive cycle; social-ecological approach; urban growth; sustainability transition

\section{Introduction}

Urban growth is becoming an important scientific issue since cities are considered one of the greatest contributors to global change by altering land use and cover, biodiversity, biogeochemical cycles and climate [1]. The large scale of contemporary urbanization process poses a serious challenge but also an opportunity to achieve sustainability [2]. The fundamental importance of urban sustainability for human well-being has been recognized in the global policy arena in the Sustainable Development Goal 11, which calls for "making cities and human settlements inclusive, safe, resilient and sustainable" [3]. By 2050, it is predicted that two thirds of people might be living in towns and cities [4]. An important consequence of these trends is that cities have become the dominant global human habitat of this century [5].

Cities have disproportionate environmental impacts at the local, regional, and global scales that spread beyond their borders $[1,6,7]$. Urban growth has generated negative impacts such as natural habitat conversion and fragmentation which negatively affects biodiversity [8], and it competes with food production globally [9]. At the same time, cities require productive ecosystems outside their borders to produce the food, the water, and renewable resources that are consumed inside the city [6]. 
It is not possible to understand the city without considering a wider territory which includes the ecosystems that support city life [10].

The pace of the urbanization process in Latin America and the Caribbean has been very rapid: in $2014,80 \%$ of population were living in urban areas, overcoming Europe (73\%), Africa (40\%) and Asia (48\%) [11]. The urban population in Colombia has increased from $40 \%$ in 1951 to $76 \%$ in 2010. Unlike other countries in the region, urban population growth is concentrated in four major cities: Bogota, Medellin, Cali and Barranquilla [12].

The Colombian Caribbean, one of the most biodiverse regions in the world, is facing great challenges due to accelerated ecosystem transformations and biodiversity loss $[13,14]$. Barranquilla, the main city in this region, has driven the major territorial transformations due to its economic dynamics and urban growth. For many reasons, the case study of the Barranquilla is particularly interesting from a social-ecological perspective. Although it shares similarities with other metropolitan areas of Latin America [15,16], Barranquilla has particular characteristics such as being in a key geographical position, having a rich natural capital, enduring a particular colonial history, having a remarkable migratory process and strongly suffering the consequences of Colombia's political and economic disturbances.

Unlike other approaches that study the processes of change in urban areas from sectorial perspectives (i.e., land cover changes [17,18] or economic and sociocultural [19]); the social-ecological systems approach has been proposed as an integrative framework for understanding the complex human-nature relations in the urban context $[5,20,21]$. This framework emphasizes the inseparable link between people and ecosystems [22]. Human societies are embedded parts of the biosphere and shape it. On the other way, societies are also shaped by, dependent on, and evolve with the biosphere [23].

Under the social-ecological systems approach, the past events can have large effects on subsequent system dynamics and lay the foundation for future changes [24]. Thus, understanding the drivers of change, defined as any natural or human-induced factor that directly or indirectly causes a change in an ecosystem [25], and how historical dynamics have shaped the current system, can provide insights into how it might be in the future [26].

In this paper, we perform a historical analysis of human-nature relationships in the Barranquilla Metropolitan Area using a social-ecological approach and the adaptive cycle metaphor to identify the main drivers of social-ecological change and provide new insights for a sustainability transition.

\section{Study Area}

The Barranquilla Metropolitan Area (BMA) is located in the Colombian Caribbean $\left(11^{\circ} 6^{\prime} 24^{\prime \prime} \mathrm{N}\right.$, $74^{\circ} 58^{\prime} 52^{\prime \prime}$ W, $477 \mathrm{~km}^{2}$; Figure 1) and comprises five municipalities of the Atlantic department: Barranquilla, Puerto Colombia, Soledad, Malambo and Galapa. Metropolitan areas in Colombia are associations of municipalities that are established to regulate issues spanning across jurisdictional boundaries. These legal institutions have administrative autonomy and the mandate to coordinate territorial planning. The BMA was officially formed in 1981.

Barranquilla city is placed at the mouth of the Magdalena River in the Caribbean Sea. The Magdalena River has a length of $1540 \mathrm{~km}$ and crosses Colombia from south to north. It delivers the highest amount of freshwater and sediment to the Caribbean Sea [27] and it is considered the main fluvial artery of the country. The BMA climate is arid warm $\left(27^{\circ} \mathrm{C}\right.$ mean annual temperature). The precipitations are torrential and scarce ( $904 \mathrm{~mm}^{3}$ /annual) [28]. The relief is flat and undulating, with two morphogenetic units: the tectonic depressions that form hills, plains and valleys and the shores where marshes form [29]. The main natural ecosystems in the study area are: (a) the tropical dry forest (TDF) that originally extended through the tectonic depressions; (b) the Magdalena River and the overflowing plains that form the riverine wetlands; and (c) the estuarine mangroves located in the shores (Figure 2). 

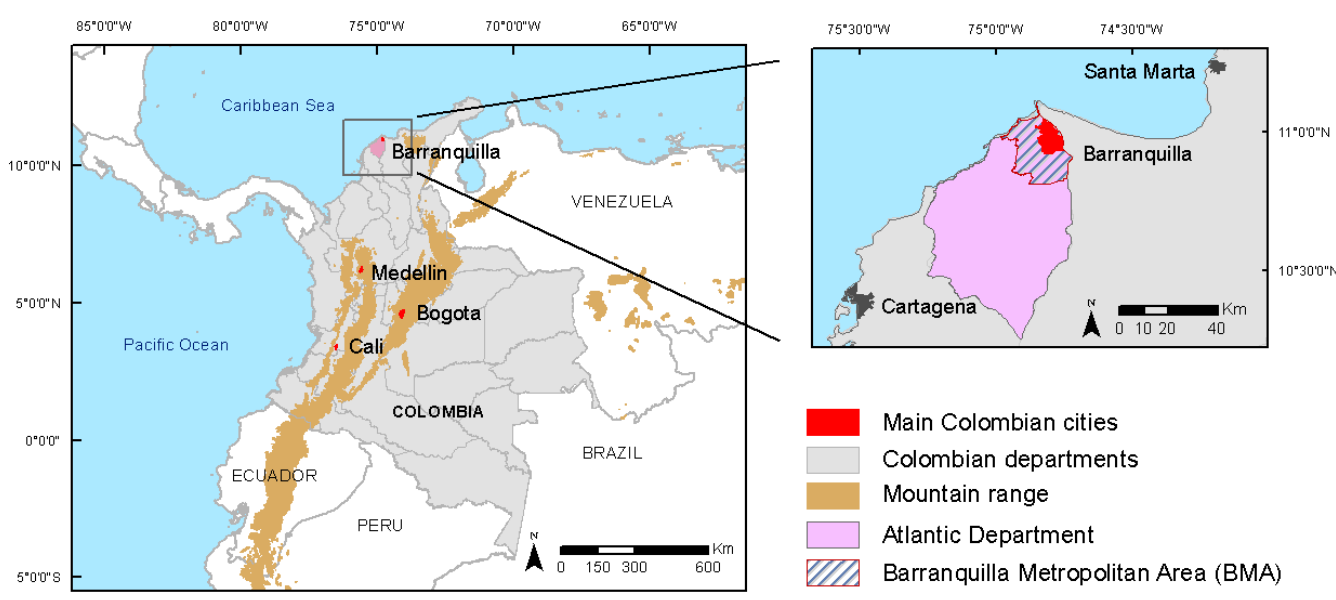

Figure 1. Map of the study area.

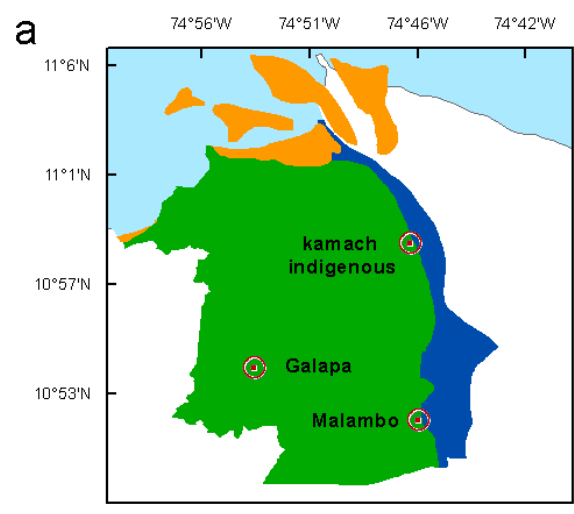

PRE-HISPANIC

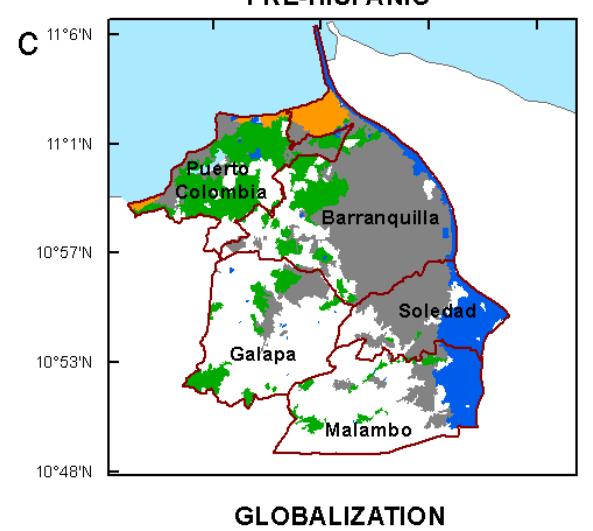

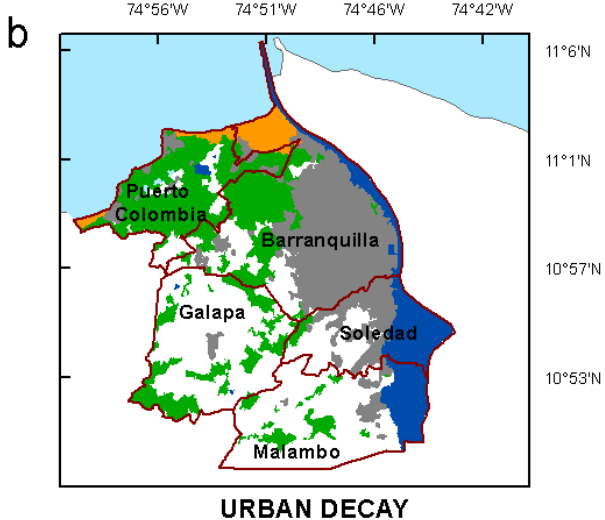

URBAN DECAY

Tropical dry forest (TDF)

Magdalena River and wetlands

Estuary and mangroves Urban

Barranquilla Metropolina Area (BMA) municipalities

C Settlement



Figure 2. Ecosystems distribution in historical periods: (a) Pre-Hispanic; (b) Urban decay (1986); and (c) Globalization (2016).

Barranquilla is the core municipality of the BMA, the capital of the Atlantic department and the main Colombian Caribbean city in both demographic and economic aspects [30]. Currently, the BMA population is $2,074,592$ people ( $4.2 \%$ of Colombian population), $99 \%$ of which are urban inhabitants [31]. Eleven percent of the BMA population belongs to some ethnic group, being $10 \%$ black and $1 \%$ indigenous. The indigenous people are concentrated in Galapa and Malambo where $28 \%$ and $4 \%$ of the population censuses in 2005 is considered indigenous. Social conditions in the BMA present a great challenge for the municipal authorities since $21.7 \%$ of the population suffer poverty ( $2.8 \%$ extreme poverty), almost six points higher that the main Colombian cities [32]. The Atlantic department's economy is based on the tertiary sector. In 2015, this sector represented $62 \%$ of GDP compared to $36 \%$ of the secondary sector and $2 \%$ of the primary sector [33]. 


\section{Methods}

\subsection{Analytical Approach}

We used the Holling's adaptive cycle to analyze the historical paths of the BMA identifying the key events and processes that mark the collapse and reorganization phases. The adaptive cycle is a useful metaphor to understand how complex adaptive systems, structured by social and ecological components, self-organize and change in nested scales of space and time [34-36]. The adaptive cycle attempts to capture the regular cycles of organization, collapse and renewal and has been applied to studying changes in social-ecological systems in various case studies [37-39]. This heuristic model has been described as moving slowly from exploitation $(r)$ to conservation $(K)$ and then moving on to a collapse or release phase $(\Omega)$, which rapidly progresses to a phase of reorganization $(\alpha)$ before turning back to exploitation $(r)$ [35]. During the growth and conservation phases, the system's capitals accumulate. The collapse phase is characterized by changes in the social-ecological system identity (i.e., key actors, system components, and interactions must disappear), involves substantial losses of social-ecological capital and the consequences of collapse must be lasting [40]. In the reorganization phase the social-ecological system regains the organization that was lost in the collapse through adjusting to the changes and beginning a new cycle. We identified cycles of change and transformation in the BMA social-ecological system based on changes found in natural capital, physical-financial capital and human-social capital [41].

\subsection{Data Sources}

We used different sources of information to identify and characterize the historical periods and the major drivers of change. We analyzed 130 publications spanning the period 1911-2017, consulted experts (historians, anthropologists and archaeologists) and reviewed historical maps. We searched and compiled available time series data related with: Barranquilla human population (census and historic data), Magdalena basin fisheries production [42], Colombian Caribbean cattle herd size [43,44], and Atlantic department GDP [33]. Additionally, changes in ecosystems distribution through time were analyzed. The pre-Hispanic ecosystems distribution was inferred based on the Colombian morphogenetic systems map [29] and a historical map of 1780 [45]. We built land cover maps of 1986 and 2016 using Landsat TM+ (1986) and OLI/TIRS (2016) satellite images (path/row 53/9 and 52/9), with a spatial resolution of $30 \mathrm{~m}$. Landsat images were classified applying a supervised classification (maximum likelihood) to obtain land cover maps at 1: 100,000 scale, using Envi 5.0 software (ESRI, New York) and then exported to ArcGis 10.1 (ESRI, New York) for further analyses [46]. Land covers were grouped into broad ecosystem types: TDF, Magdalena River and wetlands, Estuary and mangroves, and Urban. Despite the controversies on how to define the urbanization process [47], we adopted a practical approach in which the term "urban growth" was used to express the spatial expansion of urban land. This "urban land" category includes territories cover by urban, commercial and industrial infrastructure, according to the Corine Land Cover methodology adapted to Colombia [48].

Based on all this information, each of the historical periods was characterized in terms of main drivers of change, status and trends in ecosystems, socio-cultural and human well-being variables, ecosystem services supplied, and multi-scale institutional or policy frameworks that influence the dynamics of the social-ecological system.

\section{Results}

We summarize the historical social-ecological profile of BMA into five major periods: (a) pre-Hispanic; (b) Spanish conquest and colony; (c) Republic formation and economic growth; (d) urban decay; and (e) globalization (Table 1). 
Table 1. Summary of the historical periods and major events that have driven the BMA socialecological changes.

\begin{tabular}{|c|c|c|}
\hline Historical Period & Major Events & Social-Ecological Effects \\
\hline Pre-Hispanic (?-1532) & $\begin{array}{l}\text { Malambo indigenous } \\
\text { livelihoods depended on } \\
\text { a mosaic of ecosystems }\end{array}$ & - Minor impact on TDF for agriculture \\
\hline $\begin{array}{l}\text { Spanish conquest and colony } \\
(1533-1820)\end{array}$ & $\begin{array}{l}\text { The Spaniards imposed } \\
\text { a new territorial } \\
\text { organization: } \\
\text { the encomiendas }\end{array}$ & $\begin{array}{l}\text { TDF deforestation for agriculture } \\
\text { and livestock. } \\
\text { Introduction of foreign species. } \\
\text { - Indigenous collapse and loss of local } \\
\text { ecological knowledge. } \\
\text { Fundamental change in the } \\
\text { human-nature relationship towards } \\
\text { ecosystem exploitation to } \\
\text { produce wealth }\end{array}$ \\
\hline $\begin{array}{l}\text { Republic formation and } \\
\text { economic growth } \\
(1821-1957)\end{array}$ & $\begin{array}{l}\text { After independence, the } \\
\text { territory is reorganized in } \\
\text { the current departments and } \\
\text { municipalities. Population } \\
\text { and economic growth. } \\
\text { Barranquilla industrial city } \\
\text { and cattle ranch } \\
\text { exploitation consolidated }\end{array}$ & $\begin{array}{l}\text { - Intense TDF deforestation for livestock } \\
\text { and wood use. } \\
\text { - } \quad \text { Introduction of African pastures and } \\
\text { negative effects on biodiversity. } \\
\text { - Pollution of the Magdalena River } \\
\text { and wetlands. } \\
\text { - } \quad \text { Mangrove forest destruction. } \\
\text { Population growth and cultural } \\
\text { diversity increased due to national and } \\
\text { foreign immigrants }\end{array}$ \\
\hline Urban decay (1958-1989) & $\begin{array}{l}\text { City crisis due to the port } \\
\text { decline and the massive } \\
\text { rural-urban migrations }\end{array}$ & $\begin{array}{ll}\text { - } & \text { Magdalena river sedimentation } \\
\text { - } & \text { Steep population growth } \\
\text { - } & \text { Proliferation of slums on areas that were } \\
\text { - } & \text { originally occupied by TDF } \\
\text { - } & \text { TDF deforestation continued }\end{array}$ \\
\hline Globalization (1990-today) & $\begin{array}{l}\text { Neoliberal model } \\
\text { implantation, } \\
\text { new Colombian } \\
\text { Political Constitution, } \\
\text { economic recovery }\end{array}$ & $\begin{array}{l}\text { - } \quad \text { Public services improvement } \\
\text { - } \quad \text { Segregated city model } \\
\text { - } \quad \text { TDF deforestation for urban growth } \\
\text { - } \quad \begin{array}{l}\text { Industrial parks and free trade zones } \\
\text { expansion over rural soil }\end{array} \\
\text { - } \quad \begin{array}{l}\text { Magdalena river sedimentation, } \\
\text { pollution and fishing decline }\end{array}\end{array}$ \\
\hline
\end{tabular}

Tropical dry forest (TDF), Barranquilla Metropolitan area (BMA).

\subsection{Pre-Hispanic Period (?-1532)}

In the territory that is now the BMA, there were indigenous peoples in Malambo, Barranquilla and Galapa (Figure 2a). These settlements belonged to the Malambo tradition [49]. The oldest archaeological site was found in Malambo (1120 BC). Archaeological evidence shows indigenous livelihoods associated with Magdalena wetlands and TDF ecosystems used for fishing and hunting and the cultivation of bitter cassava (Manihot esculenta). It has been proposed that the first trials of horticulture in Colombia started here [49]. Cassava as a crop requires dry soils [50]; thus, these crops were grown on TDF soils. With the use of fire and macana (polished stone ax) to open clearings in forests and make space for crops [51], it began the human footprint on the TDF. However, the impact was concentrated in the immediate vicinity of the denser settlements [51]. The Malambo wetland must have been an important reserve for semi-aquatic bird hunting and fishing [49].

The history of Barranquilla indigenous occupation is still being written. Recently (June 2017) researchers announced the discovery of human and wildlife remains at the Barranquilla downtown 
dated between 1220 and 1395 AC [52]. The Barranquilla indigenous were called Kamach in the official documents of Spanish crown and were also engaged in river trade with neighboring tribes [51]. The social system was strongly coupled to the ecological system as the livelihoods depended on a mosaic of ecosystems: fishing, harvesting and hunting in the wetlands and agriculture in TDF. In this period, we can infer the ecosystems distribution as shown in Figure 2a. The estuary and mangrove ecosystems must have been highly dynamic and the landforms changed continuously, forming different connections between the river and the systems of coastal lagoons [27].

\subsection{Spanish Conquest and Colony (1533-1820)}

The arrival of the Spanish conquistadors to the "Tierrandentro" territory, name given to the north part of the Atlantic department, marked a profound social-ecological change (Figure 3). The indigenous system collapsed and gave way to the colonial system. In 1533, the conqueror Pedro de Heredia arrived on the Magdalena River coast where Barranquilla is today [51]. From 1538, the Spanish crown authorized the distribution of indigenous people and taxation, thus establishing a noble society based on the encomienda institution to ensure the extraction of surpluses from indigenous agriculture [53]. For the original Colombian peoples, the encomienda meant a severe restriction in all orders of life, i.e. freedom of movement and food gathering [54]. It is estimated that on the Colombian Caribbean coast an indigenous collapse occurred where only $10 \%$ of the original population survived [43]. With the indigenous collapse, much of the ancestral knowledge related with ecosystem management was lost. There was a fundamental change in the human-nature relationship: from ecosystems use for maintaining livelihoods to ecosystem use and transformation to produce wealth.

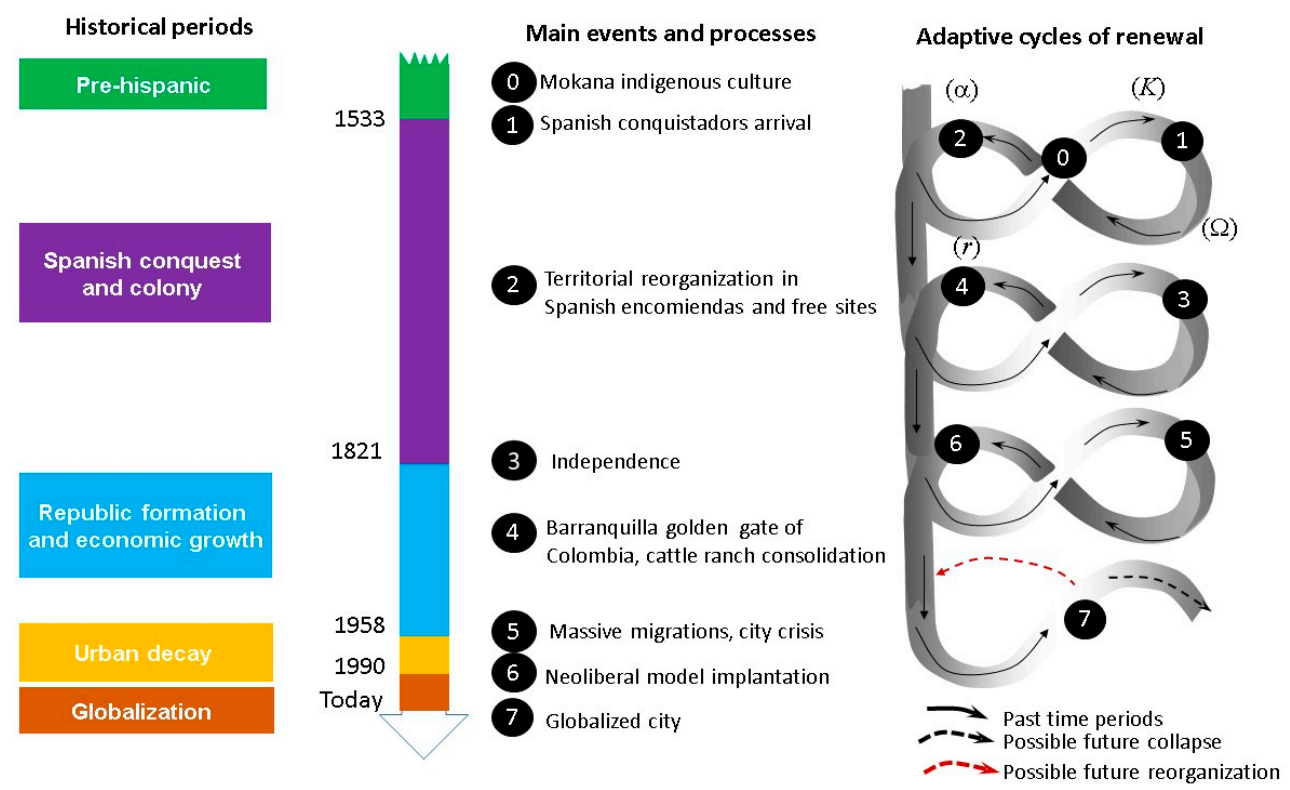

Figure 3. Historical periods, main events and processes of the BMA. showing social-ecological changes over time according to adaptive cycles. The main events and processes are placed in the specific phase of the historical adaptive cycles: $(r)$ exploitation or growth, $(K)$ conservation, $(\Omega)$ collapse or release and $(\alpha)$ reorganization.

Under the Spanish regime, some indigenous population nuclei disappeared (due to population transfer to other encomienda, or the severe demographic crisis); however, some settlement heads of encomiendas survived (e.g., Galapa and Malambo, which are today municipal capitals). The Kamach Indians of Barranquilla were given in encomienda in 1544, those of Malambo in 1555 and those of Galapa before 1551, while Soledad began its existence as a pig farm owned by a Spaniard in 1598 [54].

During this time, maize crops and cattle herds brought from Spain were stablished on TDF areas. This implied extensive clearings to establish pastures for cattle and horsestock and also for wood 
extraction. According to the historical archives, during 1561 the encomendero-the grantee-of Galapa, made the indigenous of his encomienda work by cutting "montebravo" (dry forest) to sow maize and cassava [51]. At the end of the eighteenth century, there had already been extensive logging in Tierradentro and cattle ranches had multiplied. The Magdalena wetlands were also affected by reducing their number and size for use as pastures [51]. The encomienda institution ended around 1721 and the organized indigenous groups were called resguardos (indigenous reserve) [55].

Between 1627 and 1720, the Hacienda San Nicolas was established in Barranquilla. The hacienda's landscapes were covered with dry forests and mangroves in the north. The main economic activities were the maize and cassava cultivation, extraction of wood and salt, cattle breeding and river trade [51]. Over time, the hacienda was transformed into a village or "free site" known as the "Barracas de San Nicolas". By allowing its workers to build their homes within the hacienda boundaries and with the arrival of mestizos and indigenous, the first urban nucleus was formed by 1681 . Not being under Spanish rule, as was Cartagena and Santa Marta, the free population began to grow in an environment of coexistence and tolerance, which would characterize the Barranquilla identity [55].

In 1813, Barranquilla received the recognition of "Villa" for its support to the independence movement. During the colony, there was an urban and literate social group, the Creoles, who promoted the expulsion of the Spaniards [56]. With the definitive independence in 1821 a new cycle in the history of the BMA began (Figure 3).

\subsection{Republic Formation and Economic Growth (1821-1957)}

The independence from Spain began the long process of Republic formation. From being a humble village, during this period, Barranquilla became the most important port both on the Caribbean and on the Magdalena River, and a regional center for the development on the Atlantic Coast [57]. The privileged geographical location of Barranquilla, the expansion of foreign trade and the development of steam navigation promoted the city's development.

After the independence, the Barranquilla Creoles elite demanded its political autonomy with respect to Cartagena, obtaining its definitive separation in 1910 with the Atlantic department designation with Barranquilla as its capital. The independence wars left Colombia in an economic crisis and thus the country sought the insertion in the international market with tobacco and coffee exports [58]. As the economy began to grow so did the population (Figure 4a) and the demand for meat and leather. This encouraged farmers to expand their herds and required new paddocks creation [59]. The introduction of African pastures facilitated the establishment of grasslands for their ability to out-compete weeds and prevent the forest from regenerating [60]. As the cattle industry prospered, TDF were largely removed by burning and clearing the land to become pastures $[57,60]$.

Cattle industry was the mayor economic activity of the Caribbean region. Through this period cattle industry grew steadily (Figure 4b) integrating the region into a wider national and international market [57]. Livestock farms near Barranquilla were established on the Magdalena River margin, from the city to the south. The ranchers exerted pressure on the Malambo and Galapa resguardos with the interest of appropriating their lands [61]. In 1927, the Galapa resguardo was declared extinct. The Malambo resguardo had the same fate. However, the few BMA indigenous people have maintained a legal war since 1830 for the Colombian government to recognize their rights [62]. Barranquilla growth was benefited from cattle industry. Cattle traders invested in urban development and in the emergent industrial sector [57].

The city economic growth was also promoted by the Colombian Government, which allowed the steam navigation on the Magdalena River (1824) and the exports by the Sabanilla Sea port (1849). The steam navigation flourished in Barranquilla between 1824 and 1930; in 1928 there were 133 steam boats sailing the Magdalena waters [57]. For the maintenance of the boats it was necessary the use of large quantities of firewood, exclusive fuel of river steams [63]. Likely, firewood was obtained from TDF. 

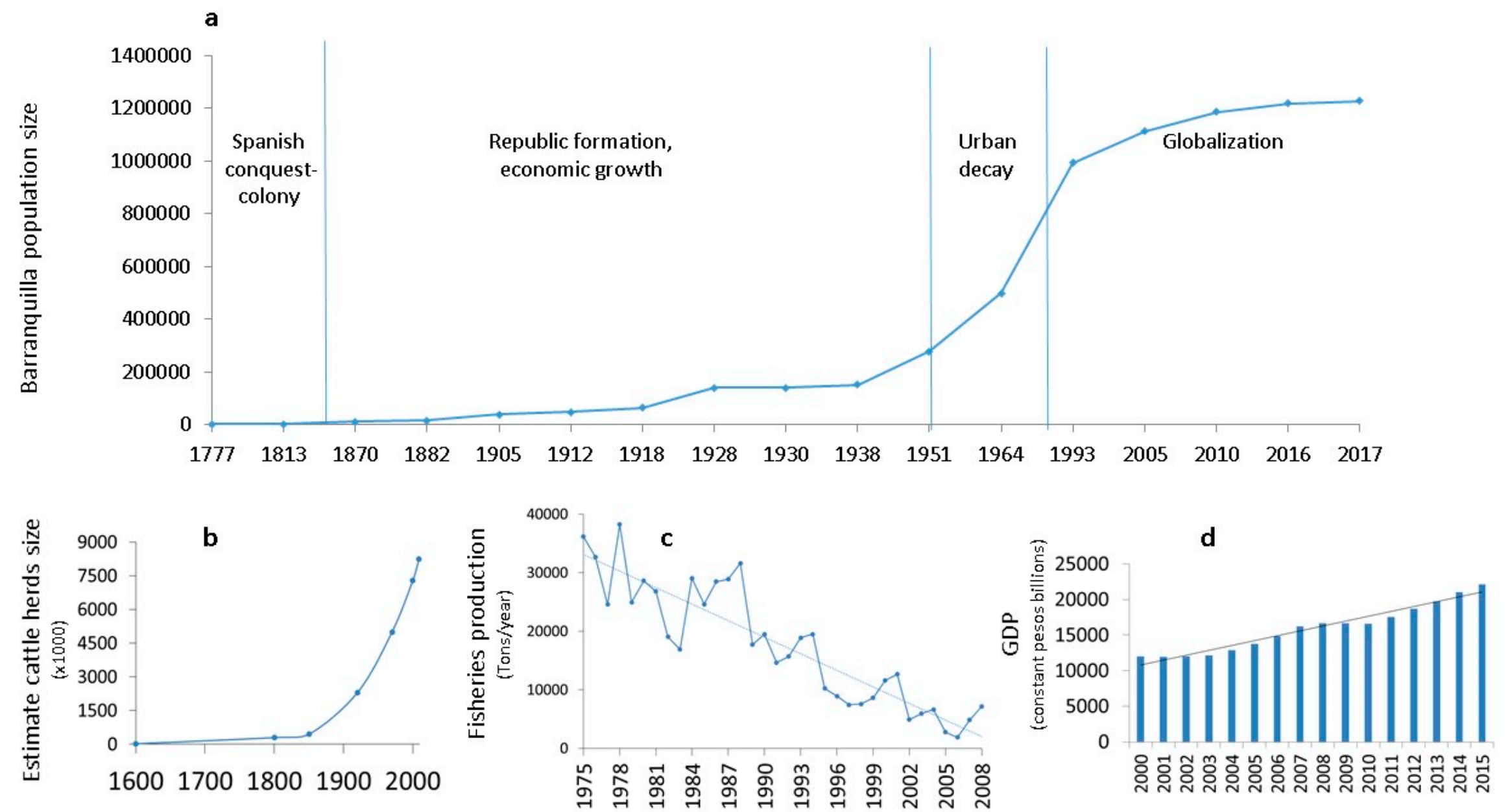

Figure 4. Time series data related with the Barranquilla Metropolitan Area (BMA): (a) Barranquilla human population (1777-2017) (Census and historic data); (b) Colombian Caribbean cattle herd size (1600-2009) [43,44]; (c) Magdalena basin fisheries production (1975-2008) [42]; (d) Atlantic department Gross Domestic Product (2000-2015) [33]. 
In the middle of the nineteenth century, Barranquilla became the obligatory route of the exports of tobacco and coffee to the European markets. The products arrived from the Colombia interior through the Magdalena River to the fluvial port of Barranquilla. From there they were transferred in small boats through difficult estuary channels to Sabanilla. When the cargo amount increased, the National Government decided to build a railroad that would connect the river port with the Sabanilla port (Figure 5). In 1871, the Bolivar Railway was inaugurated. However, Sabanilla port did not possess an appropriate harbor, so the railway was extended to Puerto Colombia, where a $4000 \mathrm{ft}$ pier was built in 1893 [57]. During the pier construction, the Puerto Colombia village consolidated (the village was founded in 1888). Through this port arrived a wave of European and Asian immigrants who found in Barranquilla a suitable place to do business and prosper. Immigrants energized industry and made Barranquilla a modern and cosmopolitan city [64,65].

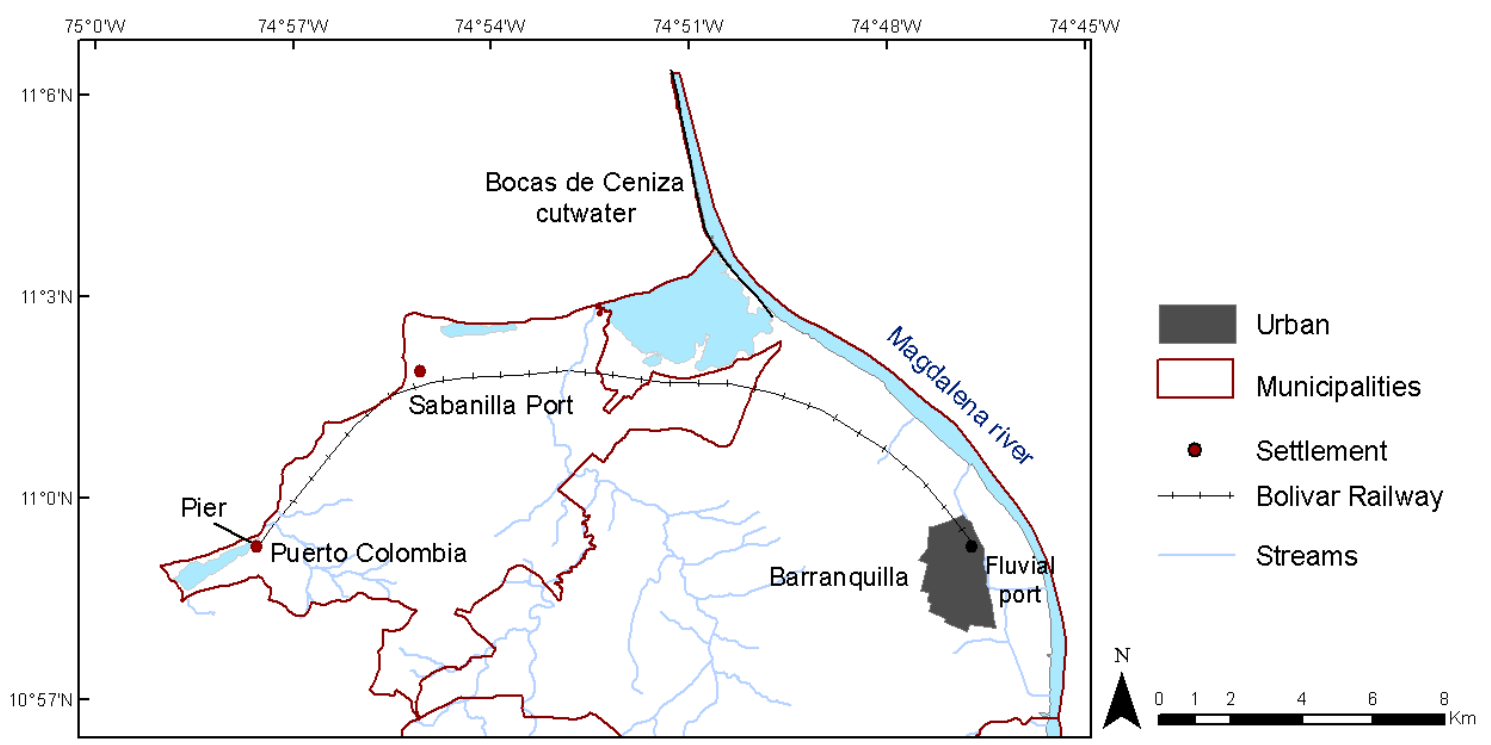

Figure 5. Map of the north of the BMA showing the location of the sites discussed in the republic formation and economic growth period (1821-1957).

The construction and maintenance of the railroad had a negative impact on the TDF because materials were taken out of the neighboring railroad forests and those of the nearby areas. "In the half-century that passed while operating this company (until 1936) thousands of "polines" or sleepers of wood were needed to replace those that were damaged" [66]. By 1906, about $60 \%$ of the country's foreign trade took the Barranquilla-Puerto Colombia route [57]. These favorable economic circumstances promoted a great commercial and industrial boom that favored Barranquilla population expansion (Figure 4a) and urbanistic growth. Between 1918 and 1938 Barranquilla had the fastest-growing population among the mayor Colombian cities. This growth was due to migratory movements and the city opportunities to offer work [67]. During this period the city was modernized, improving the provision of public services, developing banking services, as well as being a pioneer in commercial aviation throughout America. All these advances in urban development made Barranquilla deserve the appellation of "Golden Gate of Colombia" [57]. Nevertheless, urban growth was not planned and the city grew without any order.

Barranquilla's industry expanded during 1930s and 1940s, which made it the third largest Colombian industrial center [57]. The industries produced textiles, processed food and beverages [68]. However, unplanned urban growth produced pollution of the Magdalena wetland and streams, causing unhealthy conditions for the population and constant epidemic outbreaks [69].

The agriculture and fishing also developed although to a lesser extent, both activities associated with the Magdalena River [70,71]. 
In 1936, the Bocas de Ceniza jetty and the Barranquilla sea harbor were officially open giving to Barranquilla the double condition of river and seaport [57]. However, this led to a drastic transformation of the estuarine and mangrove ecosystems, the disappearance of islands at the mouth [72] and the deterioration of the Mallorquin marsh [73].

"In the vicinity of Bocas de Ceniza ... existed until about twelve years ago (1935) an extensive and dense mangrove forest that covered about $10-12 \mathrm{~km}^{2}$ of marshes. Today they have disappeared in those places, remaining only thousands of scant trunks ... the construction of the stone dam ... completely closed the water passage to the estuaries. For this reason, they have been drying up little by little." [73]

The lack of river channel maintenance caused problems to the performance of the port since 1940s [57]. This problem and the massive rural-urban migration caused a city crisis and led to the next historic social-ecological period (Figure 3).

\subsection{Urban Decay (1958-1989)}

From 1958, Barranquilla began to suffer an industrial, commercial, social and political crisis [74]. The causes were multiple. On the one hand, the Barranquilla port entered in a decline phase as exports and imports were drastically reduced. The sedimentation of the Magdalena River, product of the deforestation of mountain areas in the interior of the country [14], caused several temporary port closures [75]. The Panama Canal opening had encouraged the rise of the Pacific port of Buenaventura, which gradually displaced the Barranquilla port in importance [57]. The city industrial development was marked by port development, not by the demand for goods from the rest of the territory. Barranquilla grew as a settlement with very weak relations with the rest of the territory. Rural areas were dominated by extensive cattle ranching, with very little labor demand and thus a narrow market for the city's industrial products [76]. As the port fell, industry declined and the economy went into crisis [74]. Another cause was the massive rural-urban migrations that occurred throughout the country. The violence (1946-1965), a period of political chaos, resulted in 3 million peasants migrating from the countryside to urban areas [77].

As a result, slums expanded through Barranquilla. Between 1957 and 1982, 21 illegal settlements were created [75]. The city expanded 3672 ha between 1957 and 1993, 63\% of which was informal growth [67]. The population grew steeply (Figure 4a). This produced the conurbation of Barranquilla with Soledad (Figure 2b). Most of the growth occurred in the southwestern part of the city over shrubs and grassland areas [78] that were once TDF. The soil instability of those areas, product of geological conditions and deforestation, the lack of sewerage and the urban occupation of the streams later caused the collapse of residential sectors [79]. The city could not accommodate the arriving population. This led to the deterioration of public services provision and the quality of life. The $36.5 \%$ of the population suffered poverty and 15.7\% extreme poverty (1985), values higher than those of Bogotá, Cali and Medellin [75]. Unemployment and informal employment increased. Although there was a Regulatory Plan (1957) that sought to regulate urban growth, it was not implemented [75]. In 1981, the Metropolitan Area of Barranquilla was created as an entity that seeks to harmonize the growth of municipalities, but its weak governance did not contribute to improving the situation.

In this period TDF deforestation continued, both for the growth of the city and for wood extraction. Dugand [68] described that the few remaining patches of forest were isolated, unconnected, and extremely degraded by the action of the peasants, who exploited them by drawing wood and making charcoal, consumed in many thousands of homes in the city of Barranquilla. The next period will begin with globally induced economic changes (Figure 3).

\subsection{Globalization (1990-Today)}

In the 1990s, a slow economic recovery of the BMA began. The Colombian adoption of the neoliberal economic model and a new Colombian Political Constitution (1991) changed the framework conditions of the BMA. 
The new Constitution promoted administrative decentralization, with greater political and planning autonomy for municipalities, and the direct election of mayors. In 1993, Barranquilla was organized as a "Special, Industrial and Port District", administrative status similar to the departments, which allowed the access to more of the Nation's economic resources. The decentralization processes promoted the elaboration of municipal territorial plans (POT, in Spanish), that regulate the land-use categories. Barranquilla formulated the first POT in 2000 and revised it in 2012. The other BMA municipalities have their own plans in different update levels. In 2013, the BMA formulated the "Metropolitan Agreement" as the main planning instrument at the metropolitan scale, in harmony with the municipal POTs. The governance of BMA as an institution has been weak [80] but it is currently in the process of strengthening [81].

The neoliberal economic model has conditioned the BMA territory for foreign investment with poor results [82]. With the signing of the Free Trade Agreements (FTA) (1994-2012) it was expected that all economic activities would relocate in cities close to the sea (i.e., Barranquilla) but this has not yet happened at the expected pace [82]. The FTA with the United States, in force since 2012, has been questioned because of its negative effects on peasant economies, intensifying the crisis in the Colombian countryside [83,84]. In contrast, the FTA with the European Union, in force since 2013, excluded from the agreement some agricultural products (such as corn, rice, pork and poultry) to protect national production [85]. The expansion of free trade zones in the BMA (Law 7 of 1991) [86] has been a major consequence of these FTA that ultimately seek to expand trade between countries. Free trade zones are private areas, with large tax benefits that have fostered important land use changes in the municipalities of the BMA. The Galapa and Malambo POTs have favored the industrial parks and free trade zones expansion, affecting the rural soil. The Barranquilla rural area has also undergone changes due to the abandonment of agricultural activities and the progressive location of factories related with construction industry [87]. The effects of globalization in BMA have been mixed: the infrastructure has improved but the unemployment rate and poverty are still high and the department's economy has advanced to the tertiary sector [82].

A new political movement ruled in Barranquilla between 1992 and 2008. It enhanced the delivery of public services to the poorest sectors of the population. Since 2008, the city's economy has started to improve due to the growth of the construction sector and the investment in public infrastructures [88]. This progress was due to a new model of city management in which the Barranquilla elite regained political power (2008-today) to achieve a "competitive and integrated city on the global economy" [87]. The urban center renovation and the construction of public infrastructures on the Magdalena River bank have the objective of making the city the "Golden Gate of Colombia" that was in the republican era [87]. However, the renovation process has received some criticism considering the displacing of the poor population who lived and survived in these places [89].

The economic recovery is also evident in the urban growth of the northern area of Barranquilla and Puerto Colombia over littoral ecosystems originally covered by TDF. There, shopping malls, gated communities and private hospitals have been built for the middle and upper social classes. This area constitutes the "new Barranquilla" that is perceived as the modern, clean and organized area of the city, in contrast to the older neighborhoods that look dirty and chaotic [90]. The recreational options for the population improved as new parks and green spaces were built. However, a low percentage of the Barranquilla population benefited from these developments as they were mostly concentrated in the northern zone [90]. This increased the pattern of a segregated city, with a rich north and a poor south.

This spatial pattern of population segregation is supported by studies on the distribution of poverty and violence. The southwestern and southeastern localities of Barranquilla show a clear pattern of concentration of the poorest, least educated population, with informal jobs [91] and having higher rates of homicide cases [92]. It is noteworthy that the population of the southwestern zone has also suffered from being located in an area of serious threat of landslides [87]. As mentioned before, this zone was urbanized over areas that were cover by TDF. Thus, in Barranquilla, at least in the southern areas, deforestation, urbanization, violence and urban poverty spatially converge. 
The southern area of Barranquilla and Soledad has received the majority of the armed conflict displaced population that has reached the BMA. According to official data, in the period 1990-2016, the BMA has received a total of 214,995 displaced people (10.4\% of the BMA population) [93]. The BMA has acted as a receiving territory because the conflict's level here has been lower compared to other areas of the country. However, it must be noted that Barranquilla, as a port, has been a place of dispute between illegal groups for the control of arms smuggling and drug trafficking and has suffered from paramilitary groups actions [94].

In this period, the Magdalena River wetlands, TDF and rural areas have been negatively affected by industrial facilities location in Galapa and Malambo, the construction boom in Barranquilla and Puerto Colombia and the urban growth associated with the arrival of displaced population mainly in Soledad and Barranquilla (Figure 2c). In the Magdalena River, sedimentation rates have increased, threatening the Port's viability and increasing the flooding risk [27]. Fishing has been sharply reduced (Figure 4c) and the contamination continues without a solution [95].

This globalized metropolitan area, based on high public-private investments for urban renewal and the incorporation of the territory to the global market, is growing economically (Figure 4d) but clearly at the expense of the deterioration of its ecosystems. The BMA natural capital is highly degraded as a product of the drivers of change that have been described above. Nearly $80 \%$ of the BMA area has some degree of desertification [96] and is highly vulnerable to climate change [97]. In addition, the Magdalena River has high levels of pollution [95] and the Barranquilla city only has $0.89 \mathrm{~m}^{2}$ of green space per inhabitant [87] in comparison with the international recommendation of $9 \mathrm{~m}^{2}$ per inhabitant (World Health Organization-WHO).

\section{Discussion: Future Pathways for Sustainability Transition}

The future of a social-ecological system, such as the one described in this study, is not easily predictable and is full of uncertainties $[35,98]$. Our historical analysis revealed that the BMA territory faces great challenges to be sustainable, resilient and to bring well-being to its inhabitants. As a result of the nature-society interactions that have historically occurred in BMA, the natural capital has degraded notably, physical-financial capital has increased and the human-social capital has had periods of crisis and recovery (Figure 6). In this section, we discuss some possible future pathways that the BMA could follow in view of its past development trends.

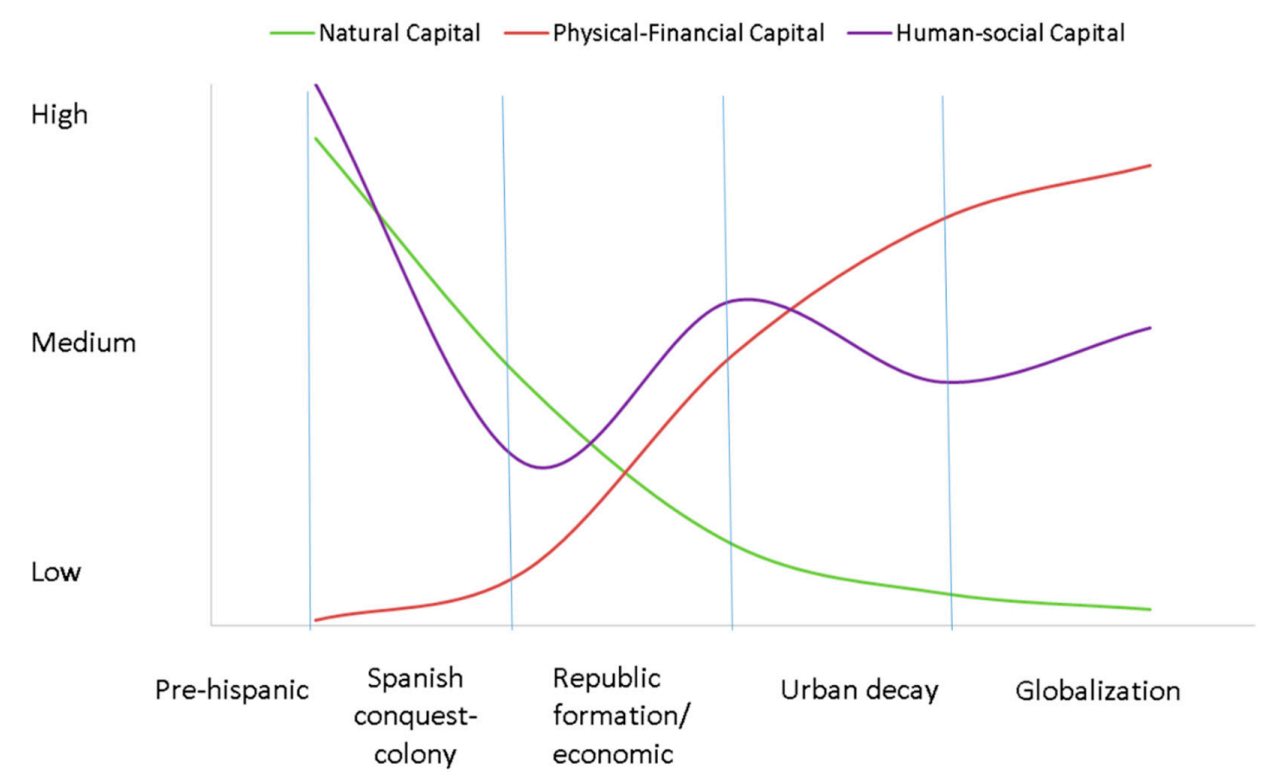

Figure 6. Hypothetical changes in natural, physical-financial and human-social capitals throughout the historical periods in the BMA social-ecological system. 
It is possible that a new collapse of the system will occur in the future due to the current depletion of its natural capital (black dashed arrow in Figure 3). As the collapse phase involves substantial losses of social-ecological capital, it is foreseeable that in the new collapse there will be decreases of the human-social and/or physical-financial capital, with undesirable consequences.

Otherwise, the system could remain in a very vulnerable $(k)$ phase of the adaptive cycle. This vulnerability would be determined by the city's dependence on distant ecosystems for the provision of some ecosystem services (e.g., the need to supply local fishing with species brought from other continents). Likewise, Barranquilla is one of the coastal cities most vulnerable to flooding related to climate change [99]. Mangrove ecosystems fulfill the function of coastal protection [100], so their destruction and transformation accentuate the BMA vulnerability to the effects of climate change. In the face of future and unknown disturbances a highly vulnerable system could collapse [35].

Avoiding a new collapse will require making changes at strategic points in the system to move towards a more sustainable and resilient state [101]. This alternative future scenario is represented in a red dashed arrow in Figure 3 and implies a reorganization of the system without going through a collapse phase.

We argue that viewing and managing the BMA as a social-ecological system would contribute to move forward in a sustainable direction. The social-ecological framework calls for an integrated vision of the territory, in which the interaction between the ecological and the social domains is mediated by the ecosystem services and the governance system [23].

For this reason, the necessary changes should consider both ecological and social domains and the interaction between them at multiple spatial scales. In the ecological domain, it is imperative to restore, conserve and value the natural capital. In the social domain changes in people sense of belonging to the territory (place attachment) must be encouraged, along with severe changes in consumption and production patterns. Abundant literature on urban and planetary sustainability call for the urgent need to reconnect with nature and for humanity to become nature stewardship [102,103]. New policies that foster environmental education and interdisciplinary science will fertilize the path to a sustainable transition.

In the interaction between social and natural domains, changes in the governance system that allow managing the natural capital for human well-being are essential. Barranquilla should lead a new process of social-ecological planning of the territory that takes into account the ecosystem services that contribute to human well-being [46]. By making more explicit human-nature links and the benefits that people derive from ecosystems, research and mapping on ecosystem services and their incorporation into planning instruments (e.g., POTs and Metropolitan agreements) could help materialize this idea. Furthermore, an adaptive governance scheme that promotes the re-organization of a social-ecological system implies establishing new institutional arrangements and the active collaboration across diverse interests and sectors [104]. The coordination of planning and development policies among the municipalities of BMA will be a necessary first step, taking into account the current differences in the municipal urban political agendas [105].

Transitions towards a more sustainable future will require fostering social capital and promoting effective social participation in ecosystem management decisions [106]. The social-ecological approach has been successfully used to guide projects that foster participation and social enrollment in ecosystem management [107]. Social learning and exchange of information between stakeholders are common elements to ensure meaningful participation [107]. Even though the Colombian law considers social participation as a fundamental requirement in land use planning and management, the real application of participatory processes has resulted in more failures than successes [108]. In Barranquilla, social participation in the POT development failed, mostly due to civil society's fear of participation in the violent context and the lack of trust in institutions [108]. Finding ways to strengthen civil organizations and empower them to participate, in a context of change and vulnerability such as that of BMA, will be essential to move towards sustainability.

Finally, despite the huge challenges ahead $[13,109]$, the Colombian peace process that is underway also opens a window of opportunity, by proposing a comprehensive agrarian reform that will improve people life in the countryside and thus improve rural-urban relationships. This scenario of change opens the possibility of rethinking the territory for human well-being and not only for economic growth. However, advances in research and policy will not be enough to face the upcoming challenges without 
also rising a renewed ethic of respect for the most disadvantaged actors in the BMA social-ecological history: indigenous and black people, peasants, urban poor and, of course, nature.

\section{Conclusions}

The social-ecological history of the BMA, explored under the lens of the adaptive cycle metaphor, revealed four cycles of organization, collapse and renewal that have led to a state of high vulnerability to future drivers of change, mostly due to the extreme degradation of the BMA natural capital. Avoiding a new collapse will require fostering changes in different parts of the social-ecological system to move towards a more sustainable and resilient state. Analyzing human-nature relationships and the historical transformations of an urban territory from a social-ecological perspective, as we have done, could be a useful tool to explore the future of other cities that face similar challenges in relation to the degradation of their natural capital. Likewise, this approach, can serve as a basis for initiating a social process of discussion about the desired future and the strategies that must be implemented to redirect the current path and improve urban sustainability.

Author Contributions: Conceptualization, J.A.-D. and C.M.; Data curation, J.A.-D.; Formal analysis, J.A.-D. and J.A.G.; Methodology, J.A.-D., C.M. and J.A.G.; Project administration, J.A.-D.; Supervision, C.M.; Validation, C.M. and J.A.G.; Writing-Original Draft, J.A.-D.; and Writing-Review and Editing, J.A.G.

Funding: J.A.-D. was funded by The Strategic Research Area on Biodiversity, Ecosystem Services and Well-Being and the Caribbean Biodiversity Center at the Universidad del Norte and the Colombian Administrative Department of Science, Technology and Innovation-Colciencias.

Acknowledgments: We are grateful to Jorge Villon, Joachim Hahn, and Javier Rivera for sharing information, documents and feedback; and Social-ecological Systems Laboratory at the Universidad Autónoma de Madrid for the support and two anonymous reviewers for their valuable suggestions.

Conflicts of Interest: The authors declare that they have no conflict of interest.

\section{References and Notes}

1. Grimm, N.; Faeth, S.H.; Golubiewski, N.E.; Redman, C.L.; Wu, J.; Bai, X.; Briggs, J.M. Global change and the ecology of cities. Science 2008, 319, 756-760. [CrossRef] [PubMed]

2. Seto, K.; Golden, J.; Alberti, M.; Turner, B.L. Sustainability in an urbanizing planet. Proc. Natl. Acad. Sci. USA 2017, 144, 8935-8938. [CrossRef] [PubMed]

3. United Nations. Sustainable Development Goals-17 Goals to Transform Our World; United Nations: New York, NY, USA, 2016; pp. 1-2.

4. United Nations. Nueva Agenda Urbana; Naciones Unidas: Quito, Ecuador, 2017; ISBN 978-92-1-132736-6.

5. Grove, J. Cities: Managing densely settled social-ecological systems. In Principles of Ecosystem Stewardship: Resilience-Based Natural Resource Management in a Changing World; Chapin, F.S., Kofinas, G.P., Folke, C., Eds.; Springer: New York, NY, USA, 2009; pp. 281-294. ISBN 978-0-387-73032-5.

6. Folke, C.; Jansson, A.; Larsson, J.; Costanza, R. Ecosystem by cities appropriation. AMBIO 1997, 26, $167-172$. [CrossRef]

7. Seto, K.C.; Reenberg, A.; Boone, C.G.; Fragkias, M.; Haase, D.; Langanke, T.; Marcotullio, P.; Munroe, D.K.; Olah, B.; Simon, D. Urban land teleconnections and sustainability. Proc. Natl. Acad. Sci. USA 2012, 109, 7687-7692. [CrossRef] [PubMed]

8. McDonald, R.I.; Marcotullio, P.J.; Güneralp, B. Urbanization and global trends in biodiversity and ecosystem services. In Urbanization, Biodiversity and Ecosystem Sevices: Challenges and Opportunities: A Global Assessment; Elmqvist, T., Fragkias, M., Goodness, J., Güneralp, B., Marcotullio, P., McDonald, R., Parnell, S., Schewenius, M., Sendstad, M., Seto, K., et al., Eds.; Springer: Dordrecht, The Netherlands, 2013; pp. 31-52. ISBN 9789400770881.

9. Van Vliet, J.; Eitelberg, D.A.; Verburg, P.H. A global analysis of land take in cropland areas and production displacement from urbanization. Glob. Environ. Chang. 2017, 43, 107-115. [CrossRef]

10. Ernstson, H.; van der Leeuw, S.; Redman, C.L.; Meffert, D.J.; Davis, G.; Alfsen, C.; Elmqvist, T. Urban transitions: On urban resilience and human-dominated ecosystems. AMBIO 2010, 39, 531-545. [CrossRef] [PubMed]

11. United Nations. World Urbanization Prospects; United Nations: New York, NY, USA, 2014; Volume 32. 
12. DNP. Mision Sistema de Ciudades; UN-Habitat: Bogota, Colombia, 2014; ISBN 978-958-8575-64-3.

13. Aldana-Domínguez, J.; Montes, C.; Martínez, M.; Medina, N.; Hahn, J.; Duque, M. Biodiversity and ecosystem services knowledge in the Colombian Caribbean. Trop. Conserv. Sci. 2017, 10, 1-41. [CrossRef]

14. Marquez, G. De la abundancia a la escasez: La transformación de ecosistemas en Colombia. In Naturaleza en Disputa: Ensayos de Historia Ambiental de Colombia 1850-1995; Palacio, G., Ed.; Universidad Nacional de Colombia: Bogota, Colombia, 2001; pp. 321-452. ISBN 958-701-076-0.

15. Delgado, A. Guayaquil. Cities 2013, 31, 515-532. [CrossRef]

16. Pinto da Cunha, J. Urbanización, Redistribución Espacial de la Población y Transformaciones Socioeconómicas en América Latina; Cepal; Naciones Unidas: Santiago, Chile, 2002; ISBN 9786070255373.

17. Xu, C.; Liu, M.; Zhang, C.; An, S.; Yu, W.; Chen, J.M. The spatiotemporal dynamics of rapid urban growth in the Nanjing metropolitan region of China. Landsc. Ecol. 2007, 22, 925-937. [CrossRef]

18. Masek, J.G.; Lindsay, F.E.; Goward, S.N. Dynamics of urban growth in the Washington DC metropolitan area, 1973-1996, from Landsat observations. Int. J. Remote Sens. 2000, 21, 3473-3486. [CrossRef]

19. Knox, P.L. The Restless Urban Landscape: Economic and Sociocultural Change and the Transformation of Metropolitan Washington, DC. Ann. Assoc. Am. Geogr. 1991, 81, 181-209. [CrossRef]

20. Grimm, N.; Charles, L.R.; Christopher, G.B.; Daniel, L.C.; Harlan, S., II; Turner, B.L. Viewing the urban socio-ecologicals system through a sustainability lens: Lessons and prospects from the Central Arizona-Phoenix LTER Programme. In Long Term Socio-Ecological Research: Studies in Society-Nature Interactions Across Spatial and Temporal Scales; Singh, S.J., Haberl, H., Chertow, M., Mirtl, M., Schmid, M., Eds.; Springer: Dordrecht, The Netherlands, 2013; pp. 117-146. ISBN 9789400711778.

21. Anderson, P.; Elmqvist, T. Urban ecological and social-ecological research in the city of Cape Town: Insights Emerging from an Urban Ecology CityLab. Ecol. Soc. 2012, 17, 23. [CrossRef]

22. Ostrom, E. A general framework for analyzing sustainability of social-ecological systems. Science 2009, 325, 419-422. [CrossRef] [PubMed]

23. Berkes, F.; Folke, C. Linking Social and Ecological Systems for Resilience and Sustainability: Management Practices and Social Mechanisms for Building Resilience; Cambridge University Press: New York, NY, USA, 1998; ISBN 0521785626.

24. Chapin, F.S.; Kofinas, G.P.; Folke, C. A framework for understanding change. In Principles of Ecosystem Stewardship: Resilience-Based Natural Resource Management in a Changing World; Chapin, F.S., Kofinas, G.P., Folke, C., Eds.; Springer: New York, NY, USA, 2009; pp. 3-28. ISBN 9780387730325.

25. Nelson, G.C.; Bennett, E.; Berhe, A.A.; Cassman, K.; Defries, R.; Dietz, T.; Dobermann, A.; Dobson, A.; Janetos, A.; Levy, M.; Marco, D.; et al. Anthropogenic drivers of ecosystem change: An overview. Ecol. Soc. 2006, 11, 29. [CrossRef]

26. Costanza, R.; Graumlich, L.; Steffen, W.; Crumley, C.; Dearing, J.; Hibbard, K.; Leemans, R.; Redman, C.; Schimel, D. Sustainability or collapse: What can we learn from integrating the history of humans and the rest of nature? AMBIO 2007, 36, 522-527. [CrossRef]

27. Restrepo, J.C.; Schrottke, K.; Traini, C.; Ortíz, J.C.; Orejarena, A.; Otero, L.; Higgins, A.; Marriaga, L. Sediment transport and geomorphological change in a high-discharge tropical delta (Magdalena River, Colombia): Insights from a period of intense change and human intervention (1990-2010). J. Coast. Res. 2016, 319, 575-589. [CrossRef]

28. IDEAM. Atlas Climatologico de Colombia; IDEAM: Bogota, Colombia, 2015.

29. IDEAM. Sistemas Morfogenicos del Territorio Colombiano; IDEAM: Bogota, Colombia, 2010; ISBN 9789588067261.

30. Galvis, L. Geografía económica del Caribe Continental. Doc. Trab. Sobre Econ. Reg. 2009, 119, 1-77.

31. DANE. Population Estimates 1985-2005 and Municipal Total Population Projections 2005-2020 by Area; DANE: Bogota, Colombia, 2010.

32. DANE. Monetary and multidimensional poverty in Colombia 2016; DANE: Bogota, Colombia, 2017.

33. DANE Departmental Accounts. Value Added by Economic Activity at Current Prices 2000-2015; DANE Departmental accounts: Barranquilla, Atlantico, Colombia, 2016.

34. Walker, B.; Salt, D. Resilience Practice: Building Capacity to Absorb Disturbance and Maintain Function; Island Press: Washington, DC, USA, 2012; ISBN 9781610912310.

35. Gunderson, L.H.; Holling, C.S. Panarchy: Understanding Transformations in Systems of Humans and Nature; Island Press: Washington, DC, USA, 2002; ISBN 1559638567. 
36. Abel, N.; Cumming, D.H.M.; Anderies, J.M. Collapse and Reorganization in Social-Ecological Systems: Questions, Some Ideas, and Policy Implications. Ecol. Soc. 2006, 11, 17. [CrossRef]

37. González, J.A.; Montes, C.; Rodríguez, J.; Tapia, W. Rethinking the Galápagos islands as a complex social-ecological system: Implications for conservation and management. Ecol. Soc. 2008, 13, 13. [CrossRef]

38. Thorkildsen, K. Social-ecological changes in a Quilombola community in the atlantic forest of southeastern Brazil. Hum. Ecol. 2014, 42, 913-927. [CrossRef] [PubMed]

39. Salvia, R.; Quaranta, G. Adaptive cycle as a tool to select resilient patterns of rural development. Sustainability 2015, 7, 11114-11138. [CrossRef]

40. Cumming, G.S.; Peterson, G.D. Unifying Research on Social-Ecological Resilience and Collapse. Trends Ecol. Evol. 2017, 32, 695-713. [CrossRef] [PubMed]

41. Knutsson, P.; Ostwald, M. A process-oriented sustainable livelihoods approach-a tool for increased understanding of vulnerability, adaptation and resilience. Mitig. Adapt. Strateg. Glob. Chang. 2006, 11, 1573-1596. [CrossRef]

42. Gutiérrez, F.D.P.; Barreto, C.; Mancilla, B. Diagnóstico de la pesquería en la cuenca del Magdalena-Cauca. In II. Pesquerías Continentales de Colombia: Cuencas del Magdalena Cauca, Sinú, Canalete, Atrato, Orinoco, Amazonas y Vertiente del Pacífico; Lasso, C., Gutiérrez, F.D.P., Morales-Betancourt, M., Agudelo, E., Ramírez -Gil, H., Ajiaco-Martínez, R., Eds.; Instituto Alexander von Humboldt: Bogota, Colombia, 2011; pp. 35-73. ISBN 978-958-8343-62-4.

43. Etter, A.; Mcalpine, C.; Possingham, H. Historical patterns and drivers of landscape change in Colombia since 1500: A regionalized spatial approach. Ann. Assoc. Am. Geogr. 2008, 98, 2-23. [CrossRef]

44. FEDEGAN. National Cattle Inventory by Department; Ministerio de Agricultura: Bogota, Colombia, 2010.

45. Sir Alexander Gibb \& Partners. Report on Studies of River Training. Works at Bocas de Ceniza from 1929 to 1966; Published by Blanco, J. 2011. Barranquilla. Obras completas I; Villalon, J., Vega, A., Eds.; Universidad del Norte: Barranquilla, Colombia, 1966.

46. Aldana-Domínguez, J.; Palomo, I.; Gutiérrez-Angonese, J.; Arnaiz-Schmitz, C.; Narvaez, F.; Montes, C. Incorporating ecosystem services and disservices into social-ecological planning in Barranquilla Metropolitan Area, Colombia. Ecosyst. Serv. 2018. submitted.

47. Brenner, N.; Schmid, C. The "urban age" in question. Int. J. Urban Reg. Res. 2014, 38, 731-755. [CrossRef]

48. IDEAM. National Legend of Land Cover, CORINE Land Cover Methodology Adapted to Colombia, Scale 1:100.000; Instituto de Hidrología, Meteorología y Estudios Ambientales: Bogota, Colombia, 2010; ISBN 978-958-806729-2.

49. Angulo, C. La tradicion Malambo; Fundacion de Investigaciones Arqueologicas Nacionales; Banco de la República: Bogota, Colombia, 1981.

50. Aguilera Díaz, M. La Yuca en el Caribe Colombiano: Del Cultivo Ancestral a Agroindustrial; Observatorio del Caribe Colombiano: Cartagena, Colombia, 2012; Volume 63, ISSN 1962-3715.

51. Blanco, J. Barranquilla. Obras Completas I; Villalon, J., Vega, A., Eds.; Universidad del Norte: Barranquilla, Colombia, 2011.

52. Rivera-Sandoval, J. Estudios Arqueologicos Para el Proyecto Ampliación de la Carrera 50 Barranquilla; Universidad del Norte: Barranquilla, Colombia, 2017.

53. Zambrano, F.; Bernard, O. Ciudad y Territorio: El Proceso de Poblamiento en Colombia; Academia de Historia de Bogota: Bogota, Colombia; Instituo Frances de Estudios Andinos: Barranco, Perú, 1993; ISBN 0768-424X.

54. Blanco, J. Encomiendas, Haciendas y Pueblos. Obras Completas Tomo II; Villalon, J., Vega, A., Eds.; Universidad del Norte: Barranquilla, Colombia, 2014.

55. Villalon, J. Cuatro momentos en la vida del centro histórico de Barranquilla. In Renovación de Centros Históricos en Grandes Ciudades Latinoamericanas; Vergara, A., Ed.; Universidad del Norte: Barranquilla, Colombia, 2008; pp. 245-267.

56. Domínguez, C.; Mendivelso, J.; Gómez, C. Construcción y deconstrucción territorial del Caribe Colombiano durante el siglo XIX. Scr. Nov. 2006, 10, 75.

57. Posada-Carbo, E. The Colombian Caribbean: A Regional History 1870-1950; Oxford University Press: New York, NY, USA, 2007.

58. Ocampo, J. Colombia y la Economía Mundial, 1830-1910; Siglo XXI: Bogota, Colombia, 1984.

59. Solano, S.; Florez, R. Sociedad, tierra y poder en los Estados Unidos de Colombia 1857-1885: El caso del estado soberano de Bolivar. Diálogos Rev. Eeectrónica Hist. 2013, 14, 81-124. [CrossRef]

60. Van Ausdal, S. Pasture, profit, and power: An environmental history of cattle ranching in Colombia, 1850-1950. Geoforum 2009, 40, 707-719. [CrossRef] 
61. Solano, S.; Florez, R. Resguardos indigenas en el Caribe colombiano durante el siglo XIX. Process. Hist. 2011, 19, 72-95.

62. Figuera, C.; Sarmiento, J.P. Las batallas jurídicas Mokaná por la autodeterminación y el reconocimiento. In Autodeterminacion Indigena en Colombia; Universidad del Norte: Barranquilla, Colombia, 2017; pp. 119-129.

63. Hettner, A. Viajes por los Andes Colombianos (1882-1884); Talleres Gráficos del Banco de la República: Bogota, Colombia, 1976.

64. Sourdis, A. Los judios sefardies en Barranquilla: El caso de Jacob y Ernesto Cortissoz. Bol. Cult. Bibliogr. 1998, 35, 31-47.

65. Meisel, A.; Viloria, J. Los alemanes en el Caribe colombiano: El caso de Adolfo Held, 1880-1927. Cuad. Hist. Econ. 1999, Banco de la República, Cartagena, Colombia.

66. Dugand, A. Observaciones botánicas y geobotanicas en costa colombiana del Caribe. Rev. Acad. Colomb. Cienc. Exactas 1970, 13, 415-465.

67. Ospino, P. El desarrollo urbano de Barranquilla y su dinamica regional 1777-1993. In Barranquilla: Lecturas Urbanas; Sanchez, L., Ed.; Observatorio del Caribe colombiano: Barranquilla, Colombia, 2003; pp. 3-46. ISBN 958-97134-4-0.

68. Solano, S.; Conde, J. Elite Empresarial y Desarrollo Industrial en Barranquilla, 1875-1930; Universidad del Atlántico: Barranquilla, Colombia, 1993; ISBN 9589555802.

69. Vidal, A.; Gonzalez, D. El tiempo de Vinyes, la Barranquilla de las primeras décadas del siglo XX. Memorias 2005, 2, 1-15.

70. Abello, J. El Departamento del Atlantico: Imprenta Americana, Barranquilla, Colombia, 1915.

71. Caballero, T. Apuntes sobre agricultura, ganadería e industria en Barranquilla durante la segunda mitad del siglo XIX. Memorias 2009, 10, 393-416.

72. Nuñez, H. La desaparicion de Isla Verde: Un desastre ecologico del siglo XX en el Caribe Colombiano. Huellas 2004, 69-70, 27-33.

73. Dugand, A. Aves del Departamento del Atlántico, Colombia. Rev. Caldasia 1947, 4, 513.

74. Bell, C.; Villalon, J. El periodo del frente nacional y la crisis de los años sesenta (1957-58-1974-75). In Historia de Barranquilla; Villalon, J., Ed.; Universidad del Norte: Barranquilla, Colombia, 2000; pp. 251-277. ISBN 958-8133-02-5.

75. Llanos, E. Una Aproximacion a la Geografia Historica de Barranquilla en el Siglo XX; Universidad del Atlantico: Barranquilla, Colombia, 2011; ISBN 978-958-8742-12-0.

76. Meisel, A. Porque se disipo el dinamismo industrial de Baranquilla? Lect. Econ. 1987, 23, 57-84.

77. Sanchez-Steiner, L.M. La ciudad-Refugio: Migración Forzada y Reconfiguración Territorial Urbana en Colombia; Universidad del Norte, Consejo profesional de Arquitectura y sus Profesiones Auxiliares: Barranquilla, Colombia, 2012; ISBN 978-958-741-526-1.

78. INGEOMINAS. Zoning the Risk of Mass Movement of the Western Slopes of Barranquilla; Department of the Atlantic: Bogota, Colombia, 2011.

79. Avila, G.; Rodriguez, E. Landslides and great soil volume changes affecting an urban area of Barranquilla, Colombia. In Landslides: Global Risk Preparedness; Sassa, K., Rouhban, B., Briceño, S., McSaveney, M., He, B., Eds.; Springer: Berlin, Germany, 2013; pp. 291-298. ISBN 9783642220876.

80. Samad, T.; Lozano-Gracia, N.; Panman, A. Colombia Urbanization Review: Amplifying the Gains from the Urban Transition; World Bank Publications: Washington, DC, USA, 2012; ISBN 978-0-8213-9522-6.

81. OULAMB. Indicadores, Fichas e Indices de Indicadores y Variables; Observatorio urbano local del Area Metropolitana de Barranquilla: Barranquilla, Colombia, 2017; ISBN 978-958-8921-30-3.

82. Baca-Mejia, W.R.; Parada, J.J. Globalization, territory and institutions: The case of Barranquilla, Colombia, 1990-2010. Econ. Reg. 2014, 8, 31-57.

83. Feola, G.; Agudelo Vanegas, L.A.; Contesse Bamón, B.P. Colombian agriculture under multiple exposures: A review and research agenda. Clim. Dev. 2015, 7, 278-292. [CrossRef]

84. Suarez, M.A.; Barberi, G.F. Efectos del TLC Colombia-EE.UU Sobre el Agro; OXFAM \& Planeta Paz: Bogota, Colombia, 2015; ISBN 978-958-58522-3-5.

85. Wolfram, D. El acuerdo de comercio preferencial entre la Unión Europea, Colombia y Perú: Contenido y Cambios al Status quo. Rev. Derecho Econ. 2011, 35, 25-53.

86. República de Colombia Law 7 of 1991, Diario Oficial No. 39.632. Available online: https:/ / www.cancilleria.gov. co/sites/default/files/Normograma/docs/pdf/ley_0007_1991.pdf1991 (accessed on 28 June 2018). (In Spanish) 
87. Alcaldia of Barranquilla Territorial Ordering Plan. 2012-2032. Tech. Support Doc. 2012, Alcaldia de Barranquilla, Barranquilla, Colombia.

88. Fundesarrollo. El Crecimiento Economico del Area Metropolitana de Barranquilla en los Ultimos Años; Fundesarrollo: Barranquilla, Colombia, 2015.

89. Teran, J. La Política de City Marketing de la Ciudad de Barranquilla y su Proyecto Renovación Urbana: Una Aproximación Analítica al GPU de La Loma; 2017.

90. Koch, F. The rules of the game and how to change them: Urban planning between formal and informal practices. A Colombian case study. Int. Plan. Stud. 2015, 20,1-17. [CrossRef]

91. Cepeda, L. Los sures de Barranquilla: La distribución espacial de la pobreza. Doc. Trab. Sobre Econ. Reg. Urbana 2011, 142, Banco de la Republica, Cartagena, Colombia.

92. Garza, N.; Nieto, L.; Gutierrez, M. El homicido en Barranquilla: Una lectura espacial. Rev. Econ. Caribe 2009, 3, 176-229.

93. Red Nacional de Información. In The Victim's Unit Counter; 2017.

94. OPPDH. Diagnostico de la Situación de Derechos Humanos y DIH del Departamento del Atlantico 2000-I Semestre 2011; Observatorio el programa presidencial de derechos humanos y DIH: Bogota, Colombia, 2011.

95. INVEMAR. Diagnosis and Evaluation of the Marine and Coastal Waters Quality of the Colombian Caribbean and Pacific; Invemar: Santa Marta, Colombia, 2017; ISBN 23898615.

96. MAVDT. Plan de Accion Nacional Lucha Contra la Desertificacion y la Sequia en Colombia; Ministerio de Ambiente, Vivienda y Desarrollo Territorial: Bogota, Colombia, 2005; ISBN 9589767923.

97. IDEAM; PNUD; MADS; DNP; CANCILLERÍA. Análisis de Vulnerabilidad y Riesgo por Cambio Climático en Colombia. Tercera Comunicación Nacional de Cambio Climático; IDEAM; PNUD; MADS; DNP; CANCILLERÍA; FMAM: Bogota, Colombia, 2017; ISBN 978-958-8971-54-4.

98. Folke, C. Resilience: The emergence of a perspective for social-ecological systems analyses. Glob. Environ. Chang. 2006, 16, 253-267. [CrossRef]

99. Hallegatte, S.; Green, C.; Nicholls, R.J.; Corfee-Morlot, J. Future flood losses in major coastal cities. Nat. Clim. Chang. 2013, 3, 802-806. [CrossRef]

100. Mukherjee, N.; Sutherland, W.J.; Dicks, L.; Hugé, J.; Koedam, N.; Dahdouh-Guebas, F. Ecosystem service valuations of mangrove ecosystems to inform decision making and future valuation exercises. PLoS ONE 2014, 9, e111386. [CrossRef] [PubMed]

101. Abson, D.J.; Fischer, J.; Leventon, J.; Newig, J.; Schomerus, T.; Vilsmaier, U.; von Wehrden, H.; Abernethy, P.; Ives, C.D.; Jager, N.W.; et al. Leverage points for sustainability transformation. AMBIO 2017, 46, 30-39. [CrossRef] [PubMed]

102. Chapin, F.S.; Power, M.E.; Pickett, S.T.A.; Freitag, A.; Reynolds, J.A.; Jackson, R.B.; Lodge, D.M.; Duke, C.; Collins, S.L.; Power, A.G.; et al. Earth stewardship: Science for action to sustain the human-earth system. Ecosphere 2011, 2, 1-20. [CrossRef]

103. Folke, C.; Jansson, Å.; Rockström, J.; Olsson, P.; Carpenter, S.R.; Stuart Chapin, F.; Crépin, A.S.; Daily, G.; Danell, K.; Ebbesson, J.; Elmqvist, T.; et al. Reconnecting to the biosphere. AMBIO 2011, 40, 719-738. [CrossRef] [PubMed]

104. Schultz, L.; Folke, C.; Österblom, H.; Olsson, P. Adaptive governance, ecosystem management, and natural capital. Proc. Natl. Acad. Sci. USA 2015, 112, 7369-7374. [CrossRef] [PubMed]

105. Koch, F. Mainstreaming adaptation: A content analysis of political agendas in Colombian cities. Clim. Dev. 2018, 10, 179-192. [CrossRef]

106. Folke, C.; Hahn, T.; Olsson, P.; Norberg, J. Adaptive governance of Social-Ecological Systems. Annu. Rev. Environ. Resour. 2005, 30, 441-473. [CrossRef]

107. Stringer, L.C.; Dougill, A.J.; Fraser, E.D.G.; Hubacek, K.; Prell, C.; Reed, M.S. Unpacking "participation" in the adaptive management of Social-Ecological systems: A critical review. Ecol. Soc. 2006, 11, 39. [CrossRef]

108. Koch, F.; Sanchez-Steiner, L.M. Participation without power: The failure of citizen participation in Barranquilla. Lat. Am. Perspect. 2016, 44, 168-183. [CrossRef]

109. Suarez, A.; Árias-Arévalo, P.A.; Martínez-Mera, E. Environmental sustainability in post-conflict countries: Insights for rural Colombia. Environ. Dev. Sustain. 2018, 20, 997-1015. [CrossRef]

(C) 2018 by the authors. Licensee MDPI, Basel, Switzerland. This article is an open access article distributed under the terms and conditions of the Creative Commons Attribution (CC BY) license (http:/ / creativecommons.org/licenses/by/4.0/). 